\title{
Pirandello and Buzzati: A Profile of the Short Story Elzeviro
}

During the 1920 s the terza pagina increasingly framed short stories that occupied its opening two columns, a section identified by the journalistic term elzeviro, after the Elzevir type used for the title and often the entire piece. The short story elzeviro's evolution forms an important chapter in the Italian art of storytelling that has yet to receive the critical attention its literary achievement and historical significance. warrant. ${ }^{1}$ For example, such collections as Pirandello's Novelle per un anno, Deledda's La casa del poeta, Bontempelli's Galleria degli schiavi and Buzzati's Sessanta racconti unite many stories that these authors expressly wrote for the terza. Nevertheless, critics have failed to analyze the short fiction within the context of the literary and journalistic tradition to which it belongs. The cases of Pirandello and Buzzati profile the short story elzeviro's origins, peak and decline while illustrating the distinct functions the form fulfilled in Italian literature and life during Fascism and the postwar period. ${ }^{2}$ The following case studies furthermore reveal the notable critical value of the stories as they appeared in their original frame. The short story elzeviri provide timely unobscured documentation of major authors' thematic and stylistic development and of new literary currents as they first emerged.

The short story elzeviro and its third page frame are quite recent literary and journalistic phenomena. Alberto Bergamini founded the terza pagina at the Giornale d'Italia in December 1901 when he designated the daily's third page a vehicle for divulgazione culturale. Conceived as a means to diffuse the ideas of Italian intellectuals among the educated public, Bergamini's program actually enjoyed widespread popularity among a demographically diverse audience. It soon became a prototype for the terza pagina institution, which remains unique to Italian journalism. During the early 1900 s the terza principally showcased in the elzeviro section articles on current social, political, cultural and artistic topics written by such renowned QUADERNI d'italianistica Volume VIII, No. 2, 1987 
scholars as the Dantista Isidoro del Lungo, the historian Alessandro d'Ancona, and literary critics Francesco d'Ovidio and Benedetto Croce. The terza also created a limited market for poetry and short fiction that attracted among other contributors Pascoli, D'Annunzio, Capuana, De Roberto, Panzini, Pirandello and Deledda.

Destined as they were for publication in newspapers, the short story elzeviri were highly susceptible to the changing journalistic and sociocultural climate that promoted the form's introduction to the third page. According to a Resto del Carlino staff member, the form originally replaced the "feuilleton, o romanzo d'appendice e soddisfaceva l'esigenza di un pubblico popolare, sprovvisto di mezzi per acquistare romanzi." Editorial and commercial goals understandably contributed to the newspapers' expansion of the short story market, but did not result in a standardization of the form. The short fiction contributed by such thematically and stylistically diverse authors as Palazzeschi, Deledda, Panzini, G. A. Borgese, Negri and Bontempelli enhanced the variety of content and form that has characterized the terza throughout its evolution. Providing an editorial perspective, Alberto Cavallari maintains that the short story elzeviro assumed a key role on the third page by serving as a counterpoint to the prevalent prosa d'arte form. ${ }^{4}$ It furthermore attracted a large audience because of the short story elzeviristi's popularity.

As early as 1901, when Pirandello began contributing his stories to the Corriere della sera, Ugo Ojetti would write "Ora che il Corriere ha cominciato a pubblicar novelle, gli altri giornali vorranno tutti pubblicar novelle." It was indeed a prophetic observation. The terza pagina, by then a widely adopted program, increasingly showcased novelle by story-telling masters. Paper shortages and the reporting of hard news interrupted the trend during WWI. But the short story elzeviro soon began to flourish with renewed vitality. The particular socio-political forces operating during il ventennio fascista markedly changed Italian journalism and the terza pagina's focus, which gradually shifted from divulgazione culturale to divulgazione letteraria. Unable to publish third page articles that reported freely on current social and cultural issues, editors increased their publication of short story elzeviri.

The Giornale d'Italia and the Corriere della sera document a striking expansion of the short story market during the early fascist 
years. During WWI and until 1922 the Milanese daily infrequently published short fiction on the third page. In 1924, however, there appeared some seventy stories. This trend began in August of 1923 when a variety of popular authors began to contribute their short stories regularly. Among the first generation of short story elzeviristi were Pirandello and Deledda, who had been major contributors to the Corriere before the war, Moretti, G. A. Borgese and Bontempelli. Within three years these writers were joined by Negri, Palazzeschi and Panzini. ${ }^{6}$ The Giornale d'Italia reflects a similar literary and journalistic trend in the mid-twenties. Through 1923 the Roman newspaper annually published an average of seven stories. In 1924 the daily began "La novella della domenica," which remained a regular feature after WWII, and also published short fiction on other days. The Giornale d'Italia and Corriere della sera each offered its readership from six to eight stories monthly and regularly published them in the elzeviro position.

As the content and form of the short story elzeviri published during Fascism suggest, the expansion of the short fiction market in newspapers has some far-reaching implications concerning the functions the form assumed in Italian life and culture. The fiction unquestionably provided entertainment to a vast audience. Yet, such stories as Bontempelli's "Un'anima in un bar," Pirandello's "Una giornata," "Di sera, un geranio," and Gianna Manzini's "Discordanze," also require a high level of reader sophistication. They reflect a general tendency characterizing the short stories published on the terza during Fascism, which was to bring into question the individual's relationship to self and to a society whose attitudes and beliefs inspired no commitment to human values or realistic hope for the future. The short story elzeviristi's voices addressed current ideologies, raising such issues as alienation, metaphysical and material uncertainty, and female self-definition in modern society. They thereby refuted the vision of reality that Fascist art aimed to promote, which Eligio Possenti described as "fede nella vita stessa, coscienza dell'oggi, sicurezza del domani" (3, cols. 1-5). From the short story elzeviri published during the twenties and thirties, there emerges a common sense of unrest and alienation from current societal ideals and conventions, which then culminates in the fictive dissolution of social reality as dramatized through symbolism and surrealistic techniques. The short 
stories that Pirandello contributed to the Corriere document this literary tendency and provide as well invaluable information concerning the author's thematic and stylistic evolution.

In 1901 Pirandello began what was to be a long affiliation with the Corriere della sera that ended with his death in 1936 . He regarded his collaboration with the Corriere as providing "la massima libertà."7 There were, however, two major conditions short story contributors were expected to observe. Alberto Albertini prudently guarded the Corriere's short story elzeviristi, and usually insisted upon exclusive agreements, as he did with Pirandello. ${ }^{8}$ Only when a story was judged inappropriate for the daily or its literary supplement La Lettura, could it appear in another publication. One should therefore conclude that after 1909 Pirandello wrote most of his stories with a third page audience in mind. This premise is further supported by Pirandello, who in a letter to Albertini stated that he varied his stories' content and form in order to "contentare un po' tutti i lettori del Corriere." The stories that appeared on the third page prior to 1927 do in fact offer a protean variety of content and form ranging from tragic to comic, and philosophical pieces that take place in regional and urban settings.

The condition that evidently caused Pirandello to submit few stories, and nearly brought an end to his affiliation with the Corriere in 1935 , concerned the editor's request that authors observe the twocolumn length designated for all pieces published in the elzeviro section. Regarding this guideline Pirandello writes:

Caro Rizzini, Le mando la novella che mi ha domandato per La Lettura. Presto gliene manderò un'altra per il Corriere. Ma a questo proposito voglio dirLe che con Aldo Borelli, il quale si lamentava con me perché non ne inviavo piú, io lamentai a mia volta la rigorosa esigenza di contenere entro le due colonne gli "elzeviri" di terza pagina.. . . . Non può immaginare che pena m'abbia fatta l'amputazione di tutta la prima parte dell'ultima novella pubblicata sul Corriere ("Fortuna d'esser cavallo"). La pena è tanta se si dovesse ripetere mi toglierebbe il piacere di pubblicare altre mie cose sul Corriere. ${ }^{10}$

Though Pirandello here portrays an inflexible editorial policy, other correspondence between the author and Corriere editors clearly indicates that the editors, anxious to retain popular artists, did not rigidly enforce the two-column elzeviro length. ${ }^{11}$ Some of Pirandello's ear- 
lier stories actually ran over three columns, which was an exceptional length for the genre. Generally, the short story elzeviri published in the Corriere and in other Italian newspapers were about 2,000 words, which corresponds with the length of novelle by such earlier masters as Boccaccio, Bandello, Sacchetti, and later, Giovanni Verga. Therefore, the short story elzerviro form continues within the tradition of brevitas that largely had defined the Italian short story genre from its beginnings. Luigi Barzini has furthermore suggested that the form's brevity "has possibly also prevented the art of story writing from disappearing during the last few decades and might possibly preserve it when it will have fallen in desuetude elsewhere" (97).

In 1923 when the short story elzeviro form gained exceptional popularity among readers and authors, no less than five stories by Pirandello appeared in the Corriere between August and November. As in earlier stories, the function of the hero's consciousness and often self-consciousness forms the fictive material that explains Pirandello's artistic vision and representation. The structural and stylistic qualities such stories as "Fuga," "Il figlio cambiato," and "Pubertà" share are principally defined by the author's concept of umorismo. Both an aesthetic and metaphysical concept, it constitutes the basis of a literary technique that encourages the reader's reflective powers by dramatically representing and opposing life as the hero perceives and experiences it, and the external confines societal attitudes, beliefs and ideals constitute. Although Bareggi, in "Fuga," perceives nature's rejuvenating and liberating powers, the protagonists in "Pubertà," "Il figlio cambiato" and "Un po' di vino" embody the unalleviated loneliness Pirandello saw as chronic to human existence.

Quite different are the compositional features and Weltanschauung that emerge from "I muricciuoli, un fico, un uccellino," published in 1931 after Pirandello's four year respite from the short story elzeviro genre. Following the publication of "Pubertà" in 1926, Pirandello dedicated himself almost exclusively to the theatre. "I muricciuoli," which was essentially forgotten until Muscarà recently discovered it in the Corriere, signals the author's return to the genre and marked stylistic changes consonant with an evolving personal and artistic vision. ${ }^{12}$ While the subject remains the human consciousness and self-consciousness, the artist's field of vision has expanded. The 
phenomenal world materializes with poetic force to inform the descriptive plane while providing the individual a sense of connectedness previously unrealized.

Unlike Pirandello's earlier short fiction, "I muricciuoli" does not follow a traditional plot structure. The story reflects the growing importance of atmosphere and effect as unifying narrative elements in the Italian short story. As the result of his mental catastrophes, Pirandello, the implied author and dramatized first-person narrator, seeks the "campagna solitaria," which affords an escape from friends and tasks awaiting him in the city (3, cols. 1-2). There is a striking interplay and mirroring between the self-conscious hero and the phenomenal world. As his field of vision narrows from the panorama to the particular, a fig tree that envelops him in "un bagno d'acre e caldo profumo," an "uccellino eterno," and "i muricciuoli" provoke his reflections concerning human existence. These three images function as leitmotifs throughout the story. They organically unite the narrator's fragmented thoughts concerning such particular sources of disillusionment as fame's equivocal nature and the malice demonstrated by a new generation of critics, with universal themes fundamental to Pirandello's earlier literary production: fragmentation of self, estrangement and the transitory nature of existence. The image of the "muricciuoli" explains, however, the story's structure and meaning.

The muricciuoli first appear as the source of the hero's melancholy. Man-made constructions, they divide the natural landscape in small sections that evoke humanity's pain, sadness and unrelenting toil. Pirandello skillfully transposes image to metaphor as the walls come to symbolize and explain human existence: "Muricce e murisechi, incamiciati e rustici, decrepiti, ma piú triste qualcuno fresco; per un trattino tesi tesi, come prepotenti e sicuri di sé, poi sghimbesci, a spanciare, torvi. ..." The human life cycle sees the naive self-assuredness of youth and the gradual loss of convictions. It is a theme that recurs to explain the imagery constellated through the fig tree, bird and low walls.

Mirroring the hero's mode of existence, the walls move him to analyze his own life as defined by the creative process and fame. Each has been a source of disillusionment. Compelled to create, he has spent a lifetime trying to arrest life's natural rhythm. However, 
the created work cannot extend the life of the inner self; fame, which proves "l'ingiuria peggiore che la sorte possa fare a un artista," and critical recognition have no regenerative properties. Unlike his fictive predecessors, whose disillusionment provided a psychological catalyst for rebellion, the hero accepts the loss of illusions as an inherent part of the search for authenticity. The final image of the muricciuoli at once balances the story's symmetry and provides a new dimension to Pirandello's world vision:

Sembra piú naturale, piú umano, che la presa del nostro cemento, la volanta, ceda con gli anni, e i blocchi delle convinzioni, del sentimenti, delle predilezioni, ch'esso manteneva saldamente, vengano giú uno per volta e finiscano di sgretolarsi sulla via. Muro sbronzolato, diroccato, largo a chi deve passare.

Speaking to the imagination, Pirandello creates a moment of epiphany that synthesizes the illusion/reality dichotomy forming the artistic nucleus for many of his earlier works.

The forgotten story "I muricciuoli" signals what will be the most constant thematic and stylistic features in Pirandello's later short story elzeviri. Old age, death, the transitory nature of human existence and the discovery of cosmic harmony in the phenomenal world preoccupy the author, who is himself in his final years. The stories range from plausible adventures in recognizable settings to fantastic occurrences meant to evoke sensations in the reader. In such stories as "Una giornata" and " Di sera, un geranio" fantasy forms the topography for inward journeys that derive their particular flavor from the author's poetically expressive use of imagery. "Di sera, un geranio" paradigmatically illustrates Pirandello's later stylistic development. The story's narrative texture and structure form solely through sensations until the final lines. As the center of consciousness moves from earthbound existence, he discovers a cosmic harmony evoked through images that vividly appeal to all the senses:

Quel verde. ... Ah, come, all'alba, lungo una proda, volle essere erba lui, una volta, guardando i cespugli e respirando la fragranza di tutto quel verde cosí fresco e nuovo! Groviglio di bianche radici vive abbarbicate a succhiar l'umore della terra nera. Ah come la vita è di terra, e non vuol cielo, se non per dare respiro alla terra! Ma ora che lui è come la fragranza di un'erba che si va sciogliendo in questo respiro, vapore ancora sensibile che si dirada e svanisce, ma senza finire, senz'aver piú nulla vicino. (3, 
cols. 1-2)

Ultimately the quest for wholeness, frustrated by life in society, is consummated through death. The hero experiences a complete connectedness with the surrounding phenomenal world while the things of society "non hanno alcun senso." Here, as in "Una giornata" and "Un'idea," the fictive dissolution of social reality through surrealistic techniques has several implications concerning the author's artistic vision and the changing literary and social climate the short story elzeviro documents during the 1930 s.

The numerous short stories Pirandello, Moretti, Panzini, and Palazzeschi wrote for the third page during the twenties generally perceive modern life through ironic incongruities between commonly accepted beliefs concerning the nature of reality and life as it is experienced. In contrast, Pirandello's later principles of representation reflect the growing use of imagination as a means to perceive and interpret the relationship between the "I" and the surrounding world. His artistic vision shows more than a casual correspondence to that of Bontempelli, who in the twenties introduced newspaper readers to a new kind of fiction. The general readership was highly conditioned to more realistic narrative forms that portrayed human emotions and events within the context of familiar social traditions, beliefs and attitudes. Yet, Bontempelli's poetics limited the literary function of common socio-cultural signs to their potential for mystery and the creation of new myths. His concept of realismo magico explains such stories as "Un'anima in un bar," "Quasi d'amore" and "La donna dei miei sogni," where commonplace points of departure dissolve into fanciful adventures that provoke the reader's amazement. Tangible reality menacingly assumes nightmarish qualities while fantastic occurrences materialize with realistic connotations. Fantasy informs the descriptive and ideological planes, repudiating daily reality's objective value and its prime function in the fiction-making process. The principles of representation characterizing Bontempelli's short story elzeviri and those belonging to Pirandello's later period reflect a new consciousness of the ontological condition and of fictive modes and attitudes.

The growing use of imagination as a perceptual tool led to renewed experimentation with short story content and forms on the third page during the twenties and thirties. The changing literary consciousness 
is particularly conspicuous in the short fiction by women writers. Grazia Deledda, Ada Negri, Gianna Manzini and such lesser known female authors as Elisa Zanella Sismondo, Maddalena Crispolti and Amalia Guglielminetti achieved a distinct voice on the terza, defined by new fictive material focusing on the complex problems of female self-definition and by structural patterns and imagery that convey woman's isolation, the duality afflicting her existence, and her constrained position in Fascist society as it confirmed and strengthened patriarchal norms. Their short story elzeviri generally assume a dual perspective; societal attitudes and institutions, marriage in particular, suppress the woman's search for wholeness, which must then proceed on an inner plane. Negri graphically depicts this process in such stories as "La Capitana" and "Signora con bambina," where the narrative forms entirely through the first-person narrator's internalization and articulation of the female protagonist's subconscious self. Though Deledda's short fiction offers remarkable thematic and stylistic variety, many of her short stories focus on women as the object of partriarchal abuse. In "Battesimi," for example, whose title links the religious rite signalling one's entrance into the Christian community with marital initiation, the author's creation of symbolic narrative describes submission and obedience to patriarchal authority as marital preconditions that force women into silence and emotional atrophy.

The female conflict between conformity to traditional roles and the need for valid means of self-definition ultimately explodes on the third page in Gianna Manzini's short story elzeviri. La guerra dei sessi becomes a necessary condition of relationships between women and men. Manzini's modern lovestory, "Discordanze," provides a singular example of the female author's vision of man perceiving woman, and furthermore exemplifies the most constant elements of her narrative. Concentrating on the perceptual process, the author employs imagery and structural motifs to merge seemingly fragmented impressions, sensations, memories and reflections. In this instance, the artistic vision articulates man's will to possess and dominate the female, who unknowingly antagonizes him with signs of her intellectual, emotional and physical autonomy. The ideological panorama created by "Discordanze" and such stylistically diverse stories as Negri's "Risveglio," Deledda's "Viali di Roma" and "Il 
primo volo," and Sismondo's "Dialogo sulla spiaggia," suggests that societal aspirations and realities governing female existence in the 1930s remain a source of duplicity, uncertainty and fragmentation, offering no conventional path to wholeness.

The movement toward symbolic, mythic and surrealistic fictive modes reordered short story poetics. The short story elzeviri by, among others, Manzini, Negri, G. A. Borgese and Alvaro document the prevalent use of structural and thematic motifs that form the unifying narrative design for fragments conveying the inner experience of modern life. Inner conflicts rarely issue in action; the narrative emphasis on perception displaces the importance of progressionally dovetailed events whose complication is resolved through a traditional denouement. While the above-cited authors transformed the perceivable world into a mirror of consciousness, Buzzati began contributing to the narrative direction away from le cose through his experimentation with myth, parable, farce and a unique fictional mode that united mimetic portrayal with surrealistic techniques. His short story elzevirista activity provides significant information regarding the state of the genre and the impact writing for the terza had on his poetics.

Relevancy was perhaps the short story elzeviro's chief canon during its evolution. The short stories published on the third page represent diverse points on the documentary spectrum. They range from Panzini's nearly censorious criticism of modern ethical decay as epitomized by current societal attitudes, institutions, and even fashion trends, to Bontempelli's "irrealistic" creations that capture the spirit of the times. Buzzati's fantastic treatment of topical subjects to express universal themes unites these two tendencies. For example, three weeks after the Soviets launched Sputnik II Buzzati's story "Il razzo lunare" appeared as his answer to the ensuing space race; speaking to the imagination, the farce cautions those who trust scientific and technological progress will improve the human condition. The modern parable "Troppo Natale," and "Rabbia di Natale," respectively published on Christmas 1959 and 1960, dramatize the loss of human concerns in a world consumed by "precipitazione, ansia, fastidio e confusione." Among other critics, Claudio Marabini has noted Buzzati's journalistic experience and documented the many historical allusions that form the realistic vein in his fiction (114 
15). However, critics have not considered Buzzati's poetics and short fiction within the context of the short story elzeviro tradition. As Buzzati's piece "La parola all'Elzeviro" indicates, the author conceived of the short story elzeviro as a particular kind of short fiction and was aesthetically aware of its special requirements. "La parola all'Elzeviro," published nearly twenty years after Buzzati joined the Corriere, reveals the author's poetics through a somewhat ironic dialogue between the "Elzeviro" and its public. Buzzatti here refers to the short story elzeviro, which is distinguished by its third page frame and Elzevir type, as "la suprema palestra letteraria" (3, cols. 1-2). This description denotes the form's significant role as a demanding literary exercise meant to strengthen intellectual and ethical powers. The author furthermore applauds the form's recreational function:

$\mathrm{Al}$ mio fianco catastrofi ed ecatombi: io parlavo d'altro, delle vecchie care cose perdute, o raccontavo agli uomini storie inventate, avventure, amori. Mi sembrava, perdonate, che loro fossero come dei bambini malati e io una mamma che cercasse di farli addormentare.

Buzzati's poetics echo the Renaissance theory of the novella, uniting utility and entertainment. The short story elzeviro fulfilled a significant role in Italian life and culture by instructing and entertaining an unprecedented number of readers, as made possible by its unique placement on the terza pagina. Nonetheless, because the short stories appeared in a highly commercial medium the form was particularly vulnerable to public taste. Underscoring the prime importance of relevance to the short story elzeviro, Buzzati attributes the form's declining popularity and future extinction to fictive material that fails to address the changing social fabric. The short stories Buzzati wrote for the Corriere's third page from about 1933 to 1972, consistently reflect his conviction that the elzeviro had to speak to the contemporary imagination while treating relevant material if the form were to survive.

Buzzati's short stories appeared frequently on the terza, sometimes as often as three times per month. They form a timely picture of current ideologies and events that contributed to a deepening existential crisis, while documenting the author's varied thematic and stylistic cycle. "Quando l'ombra scende," published in 1939, shows Buzzati's early efforts to describe humankind's inner ghosts, which is to say their fears, regrets, anxieties, guilts and desires, by visi- 
bly projecting them onto the external landscape. In this dramatic treatment of the dual self, which opposes material interests to human concerns, Sisto Tarra's subconscious desires confront him in the physical form of his childhood self. The strange event occurs one day when Sisto enjoys seemingly unshakable security. The fortyseven year old accountant has just received a promotion and delights in the idea that he is "solidamente piantato nel mondo, rispettato e temuto" (3, cols. 1-2). The sound of footsteps in the attic causes Sisto to investigate and to embark on an involuntary quest.

Buzzati's use of weak light and spreading darkness punctuates the ensuing psychological drama, informing the descriptive plane to render the spiritual environment. Distancing himself from the space where he conducts the daily task of living, Sisto ascends and enters the attic, softly illuminated by a "luce giallastra" that filters through the roof. There he discovers a young boy looking for toys. Sisto immediately recognizes the physical features of the "ladruncolo sconosciuto" as his own when he was about eleven years old.

The dialogue between Sisto and his double is narrated with realistic plausibility and leads both participants to self-discovery. Initially, Sisto believes himself to be the other. But it is a case of unreciprocated identification; the child does not perceive any part of himself in the adult's physical appearance, attitudes, or beliefs. While the hero seeks to impress the boy with his professional achievements a "buio crescente" fills the physical space, mirroring the emotional movement from expectation to disillusionment. When the child realizes who the man is, "proprio lui stesso, cosi come era stato trasformato dagli anni," his visible bitterness precipitates a violent clash between the ideal self and the conscious self. Sisto verbally attacks his other, who disappears, sealing the hero's doom, for he takes with him the man's beliefs and security.

The story's conclusion unites two themes, estrangement and life's transitory nature. Sisto's confrontation with his other, who is a manifestation of the man's subconscious needs and desires, forces him to see the illusion in his vision of reality; he achieves an awareness of the need for a social identity. Sisto recognizes his separateness from those who have formed human connections. They are not alone "come lui che ne aveva sempre disprezzato la vita e a poco a poco se ne era straniato pretendendo di fare tutto da sé." Though the ag- 
ing accountant's quest leads him to new self-awareness, it is tainted by despair. He has none of the personal ties that make life, and he cannot recapture the spontaneous connectedness with life that his childhood self possessed. Underscoring the psychological mood, the natural setting occupies the narrative foreground in the story's last line as the falling rain creates a final image of hopelessness.

Sisto Tarra's convictions, goals and ideals are symptoms of the existential crisis Buzzati and such other elzeviristi as Panzini, Moravia and Negri perceived in Italian society during the thirties, whereby material concerns precluded the nurturing of fundamental human ties and values. Still, a private orientation and sense of inwardness here define Buzzati's transformation of the subconscious self into a being that confronts his other. These qualities assume the character of collective experience in such later short story elzeviri as "La fine del mondo," "Sotto i nostri piedi" and "Uno scherzo di fine d'anno," where the author materializes phantasms who are vessels of humankind's fear of cataclysmic disaster. The war stories that Buzzati wrote for the terza while serving as a foreign war correspondent hold the ideological and artistic germ for much of the postware fiction he contributed to the Corriere. "Messaggio dall'isola misteriosa," "Ignote missioni per mare" and "La guerra è un posto lontano" offer examples of how Buzzati documented the transformational process the WWII experience worked on the human psyche during a historical period when daily reality's bizarre connotations began to challenge inventive possibilities.

Mirroring the deep social and political contradictions of the times, the short fiction published on the terza from the late 1930s through 1945 increasingly had as its subject "la macchina della guerra." Framed by photographs picturing women from all social classes who donated their wedding bands for the war cause, or by Fascist dictums evoking images of the invincible Italian soldier, the war stories contributed by, among others, Buzzati, Virgilio Lilli and Marino Moretti demystified the glorious war mythology. As the narrator observes in Buzzati's story "Messagio dall'isola misteriosa," "la guerra non è giunta con squilli di tromba o suono di schioppettate. Ma si è formata a noi intorno, silenziosamente, sul mare" (3, cols. 1-2). It is precisely the subtle delineation of an inescapable enigmatic force that makes Buzzati's artistic vision of the war more psychologically 
alarming than Lilli's graphic depictions of the war's material and human destructiveness.

"Messaggio dall'isola misteriosa," "Le mogli a terra" and "Una crudele serata" illustrate the most constant thematic and compositional features describing Buzzati's war stories. The author neither places his characters in physical combat, nor does he draw upon fantasy as a tool to depict the war. Rather, through a skillful blend of realistic detail and symbolism, the reader witnesses men, women and children as they collectively wage an intimate battle with the consuming metaphysical uncertainty and isolation WWII amplified to unprecedented dimensions. Anxiety and solitude recur as motifs throughout the stories to describe Italian life during the war, and its legacy to contemporary society. In contrast, "Una visita difficile," published in 1943, signals what would be major narrative concerns for the postwar neorealistic current whose thematics focused on the war as portrayed through candid documentary principles of representation (3, cols. 1-2). Uniting the two stylistic tendencies Buzzati's war stories exhibit is the author's detailed attention to how WWII radically and indelibly changed the contemporary perception of existence: "Occorre pure il sangue per tessere una tradizione guerriera. Nello spazio di un anno si è già fatta una trama compatta e solida che il tempo non riuscirà piú a consumare ("Ignote missioni per mare" 3 , cols. 1-2).

The social and spiritual crises of Italian collective life that Buzzati's war stories narrate explain the apocalyptic vision informing much of his later short story elzeviri. Though Marabini, whose critical observations conform with the majority of commentators, rightly maintains that metaphysical fear and anxiety are already operative in Bàrnabo delle montagne, he interprets these emotions as a response to destiny and the unpredictable, symbolized by fantasy beings and situations (116). Buzzati's poetics and fabulist creations suggest otherwise. The publication of the one-column short story "La fine del mondo" in 1944 is far from incidental. The sense of cataclysmic disaster that defines both the theme and structure mirrors with unprecedented immediacy the national consciousness as formed by current WWII events. The war amplified the perceived magnitude of destruction and made fantastic possibilities into eventualities, as described in Buzzati's story by a "pugno immenso."13 One morning it 
unexpectedly appears in the sky. The fist "Sembrava di pietra e non era pietra, sembrava di carne e non era, pareva anche fatto di nuvola ma nuvola non era. Era Dio; e la fine del mondo." The meta-context connotes, however, that the fist is not God or some cosmic force, but Buzzati's materialization of the fundamental fears afflicting humanity which daily life's events engendered. This narrative method, which he also uses in "Quando l'ombra scende" and countless other stories, uses fantasy as a tool to interpret reality and, furthermore, makes more or less unconscious states articulate to the conscious mind.

The phantasms Buzzati creates to document the psychological and social spirit of postwar Italy assume infinite guises. Still, many do possess human attributes. In "Sotto i nostri piedi" Mussolini negotiates with the devil, whose escape from the underground symbolizes the irretrievable evil let loose on the world during WWII. The tale "Hanno mangiato Adolfo Hitler" narrates Hitler's return to life in the form of a rabbit, who functions as a manifestation of Alfred UlzianoSatt's guilt for having first believed in the dictator's words, and his desire to avenge his brother and sister-in-law who died in Auschwitz. "Uno scherzo di fine d'anno" features Giovanni Mark's new year; the phantasm emerges as a soft voice and embodies the emotional spectrum of hope, fear and anxiety that the future elicits in everyone. Apparitions do not appear in such other stories as "Metamorfosi," later published under the title "Il figlio cambiato," "Il razzo lunare" and "Appuntamento con Einstein," where societal institutions and human enterprises conducted under the name of progress possess their own monstrous possibilities.

As a product of Buzzati's concept of the elzeviro's particular requirements and his consequent attempts to rejuvenate the form, his short stories creatively document the changing social fabric, and a new consciousness of the fiction-making process. His rich narrative range, which unites topical events and the fantastic through the literary modes of farce, parable, fabulation and satire, captures the contemporary sense of an increasingly bizarre reality: kidnappers, public massacres, political assassinations, atomic bomb experiments in Nevada, spaceships and Martians. His fiction furthermore reflects the rich variety of theme and style that characterized the short story elzeviro throughout its evolution. Other authors belonging to 
the second generation of elzeviristi who deserve mention for their contribution to the form include Moravia, Marotta, Soldati, Savinio, Rea and Gadda. For the most part, these writers began their literary careers under Fascist rule, whereas their predecessors were well estahlished authors before Mussolini came to power. While major authors joined Moretti and Palazzeschi, who continued to contribute short fiction through the 1950 s the short story elzeviro remained strong, despite the growing crisis Buzzatti described in "La parola all'Elzeviro."

During the postwar years new perceptions of fiction-writing gained momentum on the third page. While Buzzati, Marotta and Solari experimented with ancient myth, symbolic modes and fantasized structures to interpret contemporary reality, such authors as di San Secondo, Bonanni and Moravia showed a renewed interest in representationalism. The sense of interiority that informed much short fiction published on the terza from 1922 to 1945 burst into a social orientation thematically directed toward documenting the Italian WWII experience, the Resistance movement and the harsh substance of postwar proletarian existence. Bonanni's "Hans e Fritz" and Moretti's "Un ragazzo voleva il mitra" paradigmatically illustrate compositional features defining the neorealistic current that focused on the war and Resistance. Both authors adopt third-person impersonal narration, which merges eyewitness accounts of indiscriminate acts of brutality Italians suffered during German occupation. The detached description performs a dual function. It invests the narrative with a documental quality, enhanced by the mimetic representation of settings and situations, and makes single events suggestive of a collective Italian experience. In Moretti's story, for example, the curfew signifies "la tipica morale di guerra dell'anno di cui si parla: 1944" (3, cols. 1-2). As the narrative focus moves from the general condition to a particular incident that involves the shooting of a schoolteacher's son, the author's mode of representation underlines the tragedy's communal significance. The townspeople who give eyewitness accounts refer to the boy and the others shot with him as " il nostro ragazzo di sedici anni" and "i nostri fucilati." A constant interplay between the individual and the collective defines Moretti's story and much of the short fiction that documents the Resistance and WWII, thereby reinvesting the short story elzeviro with a social 
context. The stories furthermore suggest that the tragic realities experienced under the war's distorted ethical system had trenchant effects on the social consciousness, causing the loss of spiritual and ethical convictions, a daily sense of impending disaster, and a compelling will to enjoy life.

The increasing importance of social context and mimetic rendering in the fiction-making process is perhaps best illustrated by Alberto Moravia. Forced to stop all journalistic work during Fascist rule, Moravia resumed his collaboration with Il Popolo di Roma in 1943, and began a period of concentrated journalistic activity at $I l M o n d o$, L'Europa and the Corriere della sera. The author's return to the short story elzeviro shows his continued interest in current modes of existence. However, his artistic field of vision has shifted from the upper middle class, whose moral and spiritual inertia precludes emotionally or socially motivated action, to the Roman working class, shrewd ruffians and the unemployed. These characters are authentically engaged by reality, forced as they are to eke out a living by expedients. And they do so with imagination and with a particular style that gives new meaning to the word arrangiarsi.

Moravia's artistic representation of Rome's popular dimensions is characteristic of the prominent neorealistic interest in locality and the social aspect of character. The author almost exclusively adopts firstperson narrators who explain the reciprocal link between the characters and Rome; the storytellers' language and experience mirror their city and its prevailing socio-economic conditions. "Scherzi del caldo" exemplifies the locality/character interplay. Roman streets, quarters and sights materialize through the storyteller's oppressive experience, organically uniting the setting, atmosphere and psychological drama. As in Moravia's other short story elzeviri, events unfold in a seemingly unmediated style that features popular images, proverbs, colloquial expressions and limited Roman dialect. The memorable story "Perdipiede," for example, takes its title from a Romanesque term denoting someone who never accomplishes anything. The narrative form achieves two effects that concern the descriptive and ideological planes. Storytellers frequently minimize the ethical distance between themselves and the audience by addressing the reader. They thereby gain our confidence and sympathy for sometimes illicit actions. This process makes us vividly aware of 
the moral ambiguities of the times. Harsh realities governing existence in postwar Rome make shady actions seem reasonable. The narrative's conversational quality also disguises the tight structure defining Moravia's short fiction.

The short story elzeviri Moravia wrote for the Corriere during the 1940s and 1950s, many of which appeared in Racconti romani (1954) and Nuovi racconti romani (1959), powerfully document the literary and social climate. Uniting the countless human cases that form the rich fictive material is the sense of daily struggle coloring each storyteller's popular voice. Despite the characters' frequent failure to overcome material adversity, the Romani embody a charming resourcefulness. Moravia continued to write stories for the Corriere's third page throughout the sixties. His later short fiction shows a renewed interest in the estrangement from self and society suffered by the upper middle class. Though Moravia has remained a major contributor to the Milanese daily, now he rarely writes short story elzeviri.

During the late 1960s the number of short stories published on the terza noticeably declined. Now, it is a rare occasion indeed when the third page frames a story. There are several reasons for the form's decline, which largely relate to ongoing social, journalistic and literary changes. The introduction of paperbacks in the 1950s, while it enabled the public to purchase previously costly short story collections, diminished the need for short fiction in newspapers. Cavallari explains the effect of paperbacks, maintaining that their appearance "ha tolto al giornale la possibilità di far leggere racconti al lettore. . . . Il giornale ha preferito dunque offrire ai lettori piú saggistica, al posto della narrativa: l'elzeviro stesso si è esteso alla saggistica politica, sociale, ecc."14 The encroachment of such modern media as the television and cinema, which provide a more immediate escape from daily living, further influenced the genre's near extinction.

Yet another reason for the form's decline, more difficult to explain, is that Italian authors and publishers have turned to other genres. Cecchetti recently discussed the critical and sociological implications of this current literary phenomenon. When asked the reason for the decreasing short story market in newspapers, he explained:

Una delle ragioni principali è che in Italia non si scrivono quasi piú racconti. Infatti le stesse case editrici non vogliono pubblicare libri di rac- 
conti, perché credono che il pubblico non li voglia. Un libro di racconti (non dico di racconti ormai consacrati dal tempo, come Verga e Pirandello) non diventerà mai un bestseller, perché il lettore vuole la vicenda che abbia un principio e una conlusione, con personaggi con cui si possa identificare. $^{15}$

Critics are quick to recognize the short story as a traditionally strong genre in Italian literature; however, it is paradoxically overlooked in literary criticism. To date, Italian and foreign critics have failed to produce anything but historical listings of major Italian short story authors and collections. It may be impossible to explain why the short story genre and the short story elzeviro in particular have been so marginalized. As this preliminary study indicates, the genre is remarkably suited to capturing the sense of uncertainty and fragmentation so many modern and contemporary authors perceived in Italian life. Representing diverse points on the documentary spectrum, the short story elzeviri offer a felicitous union of skillful artistic execution and topical ideologies and events that contributed to the social climate. As the cases of Pirandello and Buzzati confirm, these generally unrevisited short stories document major authors' artistic development and the emergence of such literary currents as realismo magico, surrealism, and neorealism. The case studies furthermore show the impact writing for the third page had on short story poetics. The short story elzeviro tradition unquestionably revitalized the Italian art of storytelling by creating an unprecedented short story market for major and lesser known authors who could assist in the public's formation of consciousness. Their short story elzeviri should be analyzed also within the context of this literary and journalistic tradition, whose contribution to Italian literature and life warrants further critical attention. ${ }^{16}$

The University of Wisconsin-Milwaukee

\section{NOTES}

1 The joumalistic term elzeviro derives from a style of type introduced by the Elzevir family at Amsterdam, which was adopted for the title and frequently the entirety of pieces occupying the terza's first two columns. In a journalistic context, elzeviro essentially signifies a physical space on the terza that may showcase a wide spectrum of content and form, ranging from articles on topics 
of social, political and artistic interest to personal essays, fiction and poetry. During the years between the First and Second World Wars, elzeviro came to specify a literary genre similar in kind to the essay and prosa d'arte. As a genre, the elzeviro enjoyed marked popularity among readers and such major third page contributors as Giovanni Papini, Ugo Ojetti, whose memorable Cose viste were collected and published under the same title in 1923, and Emilio Cecchi, who was perhaps the form's most active theoretician and promoter. Pesci rossi (1920), which unites many of Cecchi's elzeviri, illustrates the elzeviro genre's most constant compositional features. The term short story elzeviro has been adopted to distinguish the short stories published on the third page from other prose forms and poetry that appeared there.

2 Given the extensive number of major authors who contributed to the short story elzeviro tradition, this paper treats Pirandello and Buzzati as case studies so as to avoid becoming a critical listing. The literary and critical documentation these authors provide about the form's development and their own short story poetics best illustrates the need to evaluate the short fiction published on the third page and its contribution to Italian literature.

3 Letter received from the Resto del Carlino, 19 March 1984.

4 Alberto Cavallari maintains in a letter to the author, 19 March 1984:

L'elzeviro nasce soprattutto come pezzo di prosa lirica, come capitolo, come bella pagina, nell'epoca in cui prevale in letteratura il capitolo, la prosa lirica, ecc. La presenza del narratore si alterna a quella del prosatore, quindi essi (Pirandello e Salvator Gotta, per esempio) hanno un ruolo decisivo: e cioè sono contemporaneamente firme di prestigio e firme popolari. 5 Ugo Ojetti, Letter to Pirandello (18 August 1909), Muscarà 46.

6 Alfredo Panzini contributed short stories and articles to a number of newspapers and joumals, among them the Giornale d'Italia, where he published from about 1919 to 1926. However, from the time he began contributing to the Corriere in 1924, most of his stories were destined for the Milanese paper's third page.

7 Luigi Pirandello, Letter to Alberto Albertini (24 October 1910), Muscarà 147.

8 Ugo Ojetti, who often functioned as intermediary between Pirandello and Corriere editors, outlines in his letter to the author of 18 August 1909 (Muscarà 46), general conditions regarding the "elzeviristi's" collaboration. Ojetti's remarks and the fiction published on the third page indicate that despite the editor's preference for a certain kind of fiction, they imposed no guidelines concerning content and form.

(L)a tua seconda novella a me piace piú della prima, destinata alla Lettura. Al direttore piaceva meno dato il tipo di novella che egli vorrebbe pel Corriere, piú d'azione che d'osservazione, e adatta ai lettori disattenti.... In ogni modo l'ha accettata, e con molto piacere, per avere la tua prosa e ... la tua firma nel Corriere. Ma ti prega di resistere agl'inviti che ti venissero fatti da altri giomali. Ora che il Corriere ha cominciato a pubblicar novelle, gli altri giomali vorranno tutti pubblicar novelle. . . E io credo 
che una novella al mese-se non passa le due colonne del Corriere-ormai tu puoi considerarla sistemata lí.

9 Luigi Pirandello, Letter to Alberto Albertini (24 December 1909), Muscarà 145.

10 Luigi Pirandello, Letter to Rizzini (8 December 1935), Muscarà 145.

11 Alberto Albertini describes in his Letter to Luigi Pirandello, 24 September 1909 (Muscarà 139) the editorial problems publishing short stories in the newspaper presented; however, he shows a willingness to compromise in order to retain popular authors:

Ci scusi se insistiamo per queste riduzioni. Non vogliamo lesinare le righe, e questo anzi ci ripugna, ma appunto uno dei pericoli che noi vediamo nella pubblicazione delle novelle è quello della eccessiva lunghezza, e perciò abbiamo dovuto, sin dal principio, stabilirci un certo numero che si supera già con tre colonne. ... PregandoLa di restare alle tre colonne Le concediamo già il limite massimo.

12 Muscarà's earlier study, "In margine ad una novella sconosciuta dell'ultimo Pirandello," is the first to treat the significance of "I muricciuoli, un fico, un uccellino" in Pirandello's artistic development. Though thought provoking, the evaluation presents several ideas that are not developed. She furthermore fails to locate Pirandello's work within the context of the short story elzeviro tradition and evaluate its relationship to the current literary climate.

13 Though the historical allusions in Buzzati's "La fine del mondo" 3, col.1, may seem so obvious as to warrant little attention, this story signals the beginnings of a contemporary reality whose connotations become increasingly fantastic, and in a sense challenge the literary imagination. It furthermore offers a new approach to the author's fiction, for it clearly shows how Buzzati projects, in a fabulist manner, his characters' inner world onto the external landscape.

14 Cavallari, letter to the author.

15 Letter received from Giovanni Cecchetti, 21 March 1984.

16 I extend grateful acknowledgement to Giovanni Cecchetti, Pier Maria Pasinetti, Alberto Cavallari and the Resto del Carlino editorial staff for the critical and editorial information that they generously provided regarding the short story elzeviro.

\section{WORKS CITED}

BARZINI, Luigi. Kenyon Review International Symposium on the Short Story. IV.32.1 (1970).

BUZZATI, Dino. "La parola all'Elzeviro." Corriere della sera 22 Sept. 1948.

_. "Messaggio dall'isola misteriosa." Corriere della sera 9 March 1940. "Una visita difficile." Corriere della sera 4 July 1943.

"Ignote missioni per mare." Corriere della sera 10-11 June 1941.

"La fine del mondo". Corriere della sera 7 Oct. 1944.

MARABINI, Claudio. Gli anni sessanta: narrativa e storia. Milan: Rizzoli, 
1969.

MORETTI, Marino. "Un ragazzo voleva il mitra." Corriere della sera 5 Jan. 1949.

MUSCARÀ, Sarah Zappula. "In margine a una novella sconosciuta dell'ultimo Pirandello." Le novelle di Pirandello: atti del sesto convegno intemazionale di studi pirandelliani, ed. Stefano Milioto. Agrigento: Centro nazionale di studi pirandelliani, 1980: 191-207.

MUSCARÀ, Sarah Zappula, ed. Luigi Pirandello: carteggi inediti. Rome: Bulzoni, 1980.

PIRANDELLO, Luigi. "I muricciuoli, un fico, un uccellino." Corriere della sera 18 Oct. 1931.

"Di sera, un geranio." Corriere della sera 6 May 1934.

POSSENTI, Eligio. "Volontà costruttiva e realtà nazionale nella letteratura fascista dell'anno XII." Corriere della sera 27 Oct. 1935. 